\title{
Effects of Hypophysectomy, Prolactin, and Growth Hormone on Growth of Postmetamorphic Frogs ${ }^{1}$
}

\author{
PATRICIA S. BROWN ${ }^{2}$ AND B. E. FRYE \\ Department of Zoology, The University of Michigan, Ann Arbor, Michigan
}

\author{
Received August 7, 1968
}

\begin{abstract}
Hypophysectomy of juvenile postmetamorphic frogs (Rana pipiens) reduced growth (wet weight and length) compared to sham hypophysectomized controls. Mammalian growth hormone at doses of $10-50 \mu \mathrm{g} /$ day promoted growth in intact frogs during a 2-month period. However, $5 \mu \mathrm{g} /$ day of $\mathrm{GH}$ for 1 month did not promote growth. Mammalian prolactin did not promote growth in postmetamorphic frogs over a 2 -month period at doses between 5 and $50 \mu \mathrm{g} / \mathrm{day}$.
\end{abstract}

The hormonal regulation of growth in amphibian larvae has recently received considerable attention (Berman et al., 1964; Etkin and Gona, 1967;Bern et al., 1967; Remy and Bounhiol, 1965, 1966). The view has emerged that in the tadpole stages of development a prolactin-like pituitary hormone is involved in promoting growth as well as in inhibiting metamorphosis. The evidence relating to this view is discussed in a previous paper (Brown and Frye, 1969).

Little work has been done, however, on the regulation of growth by pituitary hormones in the postmetamorphic stages of amphibians, and there is no indication whether a situation similar to that in larvae might exist. Moreover, there have been no experiments with hypophysectomized animals indicating whether the pituitary

\footnotetext{
"This work was supported in part by an American Cancer Society Institutional Research Grant (IN-40-14) through the University of Michigan Cancer Research Institute, and a National Institutes of Health Training Grant Fellowship (NIH ZTIGM939).

${ }^{2}$ Presenl address: Department of Biological Sciences, State University of New York, Albany, N. Y. 12203. This is part of a thesis submitted in partial fulfillment of the requirements for a Ph.D. degree in the Department of Zoology, The Universiby of Michigan.
}

is in fact involved in the regulation of somatic growth in postmetamorphic amphibians. However, Epple et al. (1966) reported that starved hypophysectomized toads lost weight faster than the starved controls. It has been demonstrated that hypophysectomy arrests regeneration (Hail and Schotté, 1951) and that both prolactin and growth hormone promote regeneration (Niwelinski, 1958; Wilkerson, 1963) in adult urodeles. But the relevance of this information to the problem of growth control is not certain in view of the possibility of basic differences in the cellular processes of growth and regeneration, or in the mechanisms by which hormones might aifect each of these processes. The prevalent situation in higher vertebrates would lead one to expect growth hormone to be the primary growth-promoting agent in the adult, but scattered instances of growth stimulation by prolactin are known (see reviews of Riddle, 1963, and Meites and Nicoll, 1966), and the work of Licht (1967) and Licht and Jones (1967) with lizards opens up the possibility that prolactin is an important growth regulator in some groups.

The purpose of this report is to describe the effects of hypophysectomy, prolactin, and growth hormone on growth of juvenile postmetamorphic frogs, Rana pipiens. 


\section{MATERIALS AND METHODS}

H'rogs

The postmetamorphic Rana pipien's used were collected in Kalkaska and Oakland Counties, Michigan, in September and October, 1967. They were small juveniles which had probably metamorphosed the same summer. They were maintained on flies and crickets at room temperatures until they were used in an experiment.

The method of Frye (1969) was used to hypophysectomize the frogs and is briefly described below. The frogs were anesthetized with MS 222 (Sandoz). An incision was made in the skin of the roof of the mouth of an anesthetized frog with a sharp scalpel. A dental drill was used to drill a hole in the parasphenoid and expose the piluilary. The entire pituitary was removed with either fine forceps or a mouth pipette. Using a dissecting microscope, many of the animals were chcekcd at the end of the experiment for pituitary remnants and none were found. Sham hypophysectomies were done on control animals in which the pituitary gland was exposed but not removed.

A week after hypophysectomy the frogs were separated into two groups; (1) those eating normally, which were then put into a group that were fed live flies and crickets and (2) those feeding subnormally, which were then force-fed on liver and mealworms. Each of these groups had a corresponding control, sham-hypophysectomized group. All of the groups were fed two or three times per week.

Several weeks after operation many of the frogs became sensitive to slight changes in the environment and would react with spasms. This was corrected by keeping the frogs in a $0.1-0.3 \%$ sodium chloride solution. The concentration necessary to prevent convulsions increased the longer the frogs had been hypophysectomized.

In the experiments in which hormones were administered, inlact frogs were used. Due to their increased mortality and susceptibility to infection, it was not feasible to use hypophysectomized frogs which did not tolerate well the daily injections and handling. The volume of hormone or saline solution that each animal received was $0.05 \mathrm{ml}$ per injection. Injections were made intraperitoneally.

The hormone-treated frogs were kept in individual containers and fed three or four times per week on a diet consisting of flies. crickets mealworms, and liver. Each frog received the same quantity of food material at each feeding.

Measurements were made of hypophysectomized frogs at least once a month and hormone- treated frogs were measured every 2 weeks. The size of the frogs used in these experiments ranged from $34-47 \mathrm{~mm}$ and $4-10 \mathrm{~g}$ at the beginning of the experiments. Length was determined by using a pair of calipers to measure length from the snout to the tip of the urostyle. In all of the experiments the frogs were kept at temperatures of $20-23^{\circ} \mathrm{C}$ and light conditions of $12-14 \mathrm{hr}$ of light per day.

\section{Homones}

The pituitary hormones used were Mann ovine prolactin (approximately $20 \mathrm{IU} / \mathrm{mg}$ and $\mathrm{NIH}$ bovine growth hormone (GH) (B-12; 0.97 USP units $/ \mathrm{mg}$ ). The hormone solutions were made up by dissolving the powdered hormone in $0.7 \%$ $\mathrm{NaCl}$ made basic with dilute $\mathrm{NaOH}$. The solution was subsequently brought to $\mathrm{pII} 8$ using dilute $\mathrm{HCl}$ in saline. A solution of $0.7 \% \mathrm{NaCl}$ was used to bring the hormone solution to the desired concentration. The hormone solutions were made up every 4 days and kept at $4^{\circ} \mathrm{C}$ when not in use.

\section{RESULTS}

\section{Effects of Hypophysectomy of Postmetamorphic Rana pipiens}

To determine if the pituitary gland is necessary for normal growth in young frogs, two experiments were done comparing length and weight changes in hypophysectomized frogs with those of shamhypophysectomized frogs.

In the experiment illustrated in Fig. 1 the frogs were hypophysectomized or shamhypophysectomized within a 3-day period. Feeding began approximately a week after operation. Both control and hypophysectomized frogs were force-fed, primarily on beef liver and mealworms. Many of the hypophysectomized frogs appeared to have a decreased appetite and even the quantity of food they could ingest when force fed was lower than controls. Consequently all of the frogs were fed an amount equal to the maximum capacity of the hypophyscctomized animals. The maximum capacity was assessed by the maximum quantity of force-fed food they would swallowbeyond this they would eject food within a few minutes.

The frogs were measured several times during an 11-week period but it was not 

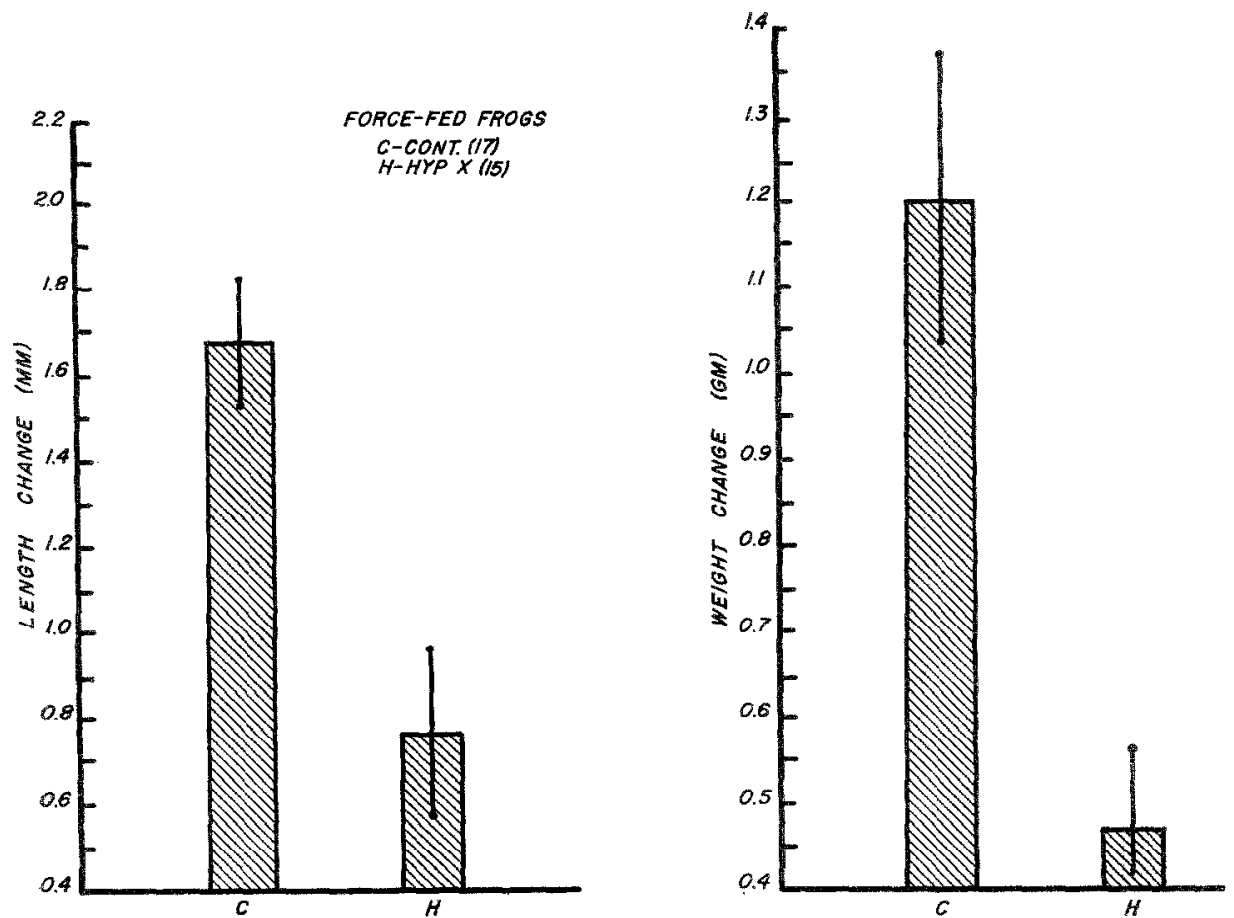

Fig. 1. Mean length and weight changes \pm standard errors of sham-operated controls (C) and hypophysectomized (H) postmetamorphic $R$. pipiens force-fed on liver and mealworms for 11 weeks.

until after $6-8$ weeks that the controls had grown sufficiently to be measurably different from the hypophysectomized animals. The length and weight changes in the two groups for an 11-week period are shown in Fig. 1. The total changes were small but the means of the two groups differed significantly in length $(p<.005)$ and weight $(p<.001)$.

The second experiment (Fig. 2) was similar to the first except that the frogs were kept in individual containers and fed live flies and crickets two or three times a week. The data from frogs whose appetites decreased (i.e., those which refused to eat the standard food allocation) during the course of the experiment were not used.

The weight and length changes of the hypophysectomized and control groups for the 7-week period are shown in Fig. 2. Both length and weight of the hypophysectomized frogs decreased to a small extent while length and weight of the controls increased. The means of the two groups differed for both parameters $(p>.05$, length; $p>.001$, weight).

\section{Effect of Prolactin and GH Treatment. on Postmetamorphic Frogs}

To determine if either GH or prolactin could affect growth in postmetamorphic $R$. pipiens, intact small frogs were weighed and measured and divided into five groups. The firsi 30 days they were treated as follows:

Group A, 0.7\% NaCl; Group B, $5 \mu \mathrm{g}$ ovine prolactin/day; Group C, $25 \mu \mathrm{g}$ ovine prolactin/day; Group D, $5 \mu \mathrm{g}$ bovine $\mathrm{GH} /$ day; and Group $\mathrm{E}, 25 \mu \mathrm{g}$ bovine $\mathrm{GH} /$ day. Injections were given daily. After 30 days the hormone doses were doubled in groups B, C, D, and E. The experiment was continued for another 26 days at the higher doses.

The length changes for the five groups for the first and second months of treatm ment are shown in Table 1. In the first month only the high GH-treated group (E) differed significantly from controls (A) $(p<.001)$. When the doses were doubled during the second month only group D differed significantly from con- 

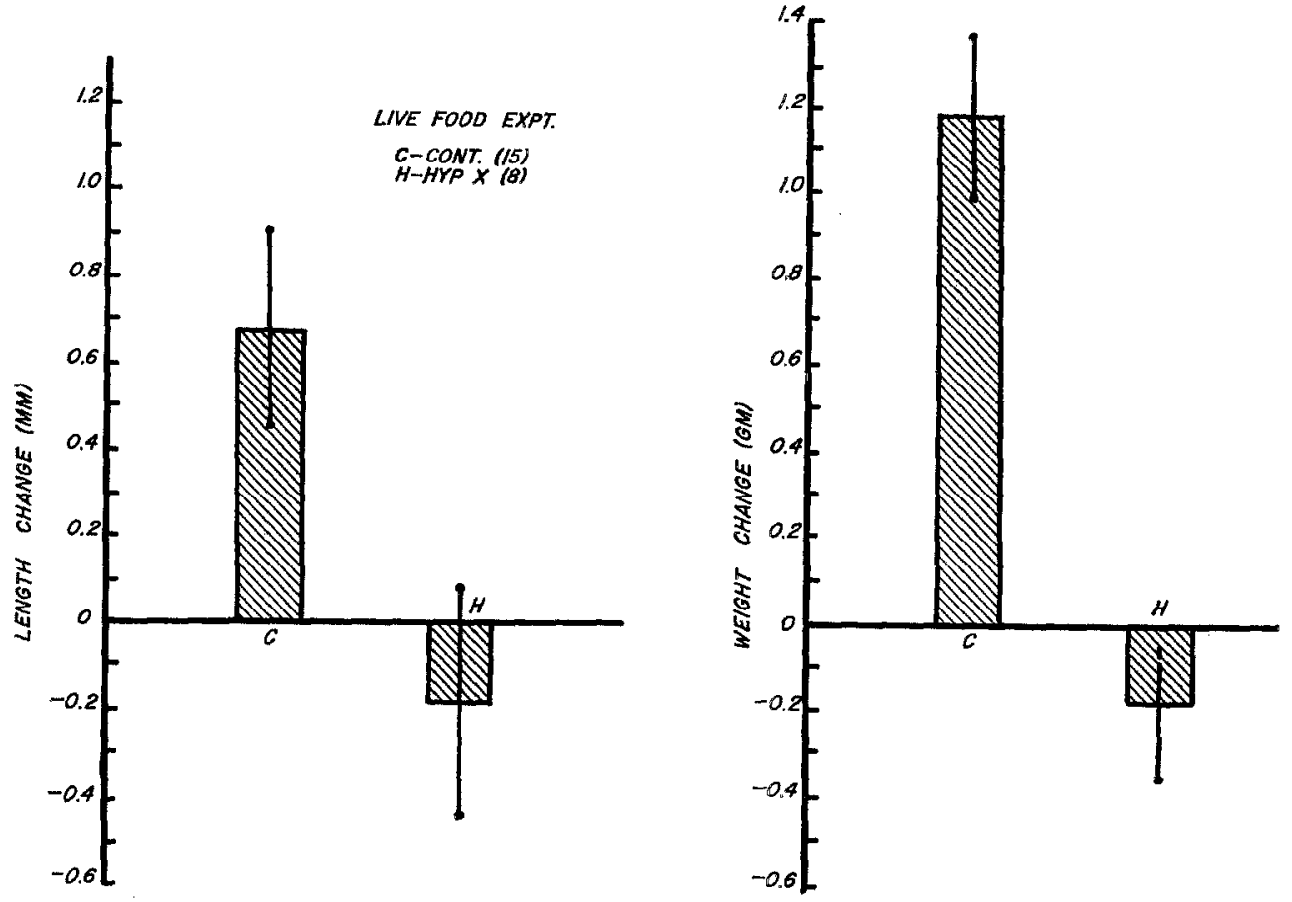

FIG. 2. Mean length and weight changes \pm standard errors of sham-operated controls (C) and hypophysectomized (H) postmetamorphic R. pipiens fed live flies and crickets for 7 weeks.

trols $(p<.05)$. The total length and weight changes for the 2-month period are shown in Fig. 3. If the length changes are combined for the 2 months, only the highest $\mathrm{GH}$ group (E) differed significantly from controls $(p<.01)$. The weight changes of both $\mathrm{D}$ and $\mathrm{E}$ differed from the control group $(p<.01, \mathrm{D} ; p<.02, \mathrm{E})$.

From this experiment it appears that postmetamorphic frogs responded by an increase in both weight and length to longterm GH treatment. The optimum GH dose appeared to be between $10-25 \mu \mathrm{g} /$ day. When group $\mathrm{D}$ was treated with $5 \mu \mathrm{g} /$ day GH no response was seen while at the same time the $25 \mu \mathrm{g} /$ day dose was effective. But when the dose for $\mathrm{E}$ was increased to $50 \mu \mathrm{g}$, it responded to a lesser extent than $\mathrm{D}$, which was receiving $10 \mu \mathrm{g}$. Prolactin had no significant effect upon either length

TABLE 1

Length and Weight Changes in Frogs Treateo with Saling, Prolactin (P), ano GH for a 2-MoN'TH PERIOD ( $\mathrm{n}=$ number of animals)

\begin{tabular}{ccccccc}
\hline Group & $n$ & Treatment & $\begin{array}{c}\text { Length change } \\
(\mathrm{mm}) \text { Mean } \pm \mathrm{SE}\end{array}$ & Treatment & $\begin{array}{c}\text { Month } 1 \\
\text { (mm) Mean } \pm \mathrm{SE}\end{array}$ \\
\hline $\mathrm{A}$ & 11 & Saline & $0.32 \pm .14$ & Saline & $1.18 \pm .18$ \\
$\mathrm{~B}$ & 11 & $5 \mu \mathrm{g} \mathrm{P} /$ day & $0.45 \pm .14$ & $10 \mu \mathrm{g} \mathrm{P} /$ day & $1.32 \pm .19$ \\
$\mathrm{C}$ & 14 & $25 \mu \mathrm{g} \mathrm{P} /$ day & $0.61 \pm .18$ & $50 \mu \mathrm{g} \mathrm{P} /$ day & $1.21 \pm .19$ \\
$\mathrm{D}$ & 13 & $5 \mu \mathrm{g} \mathrm{GH} /$ day & $0.23 \pm .15$ & $10 \mu \mathrm{g} 6 \mathrm{H} /$ day & $1.88 \pm .21^{a}$ \\
$\mathrm{E}$ & 13 & $25 \mu \mathrm{g} \mathrm{GH} /$ day & $1.11 \pm .14^{b}$ & $50 \mu \mathrm{g} 6 \mathrm{H} /$ day & $1.69 \pm .25$ \\
\hline
\end{tabular}

a Differed significantly from group $\mathrm{A} ; \boldsymbol{p}<.05$.

${ }^{b}$ Differed significantly from group $A_{;} p<.001$. 

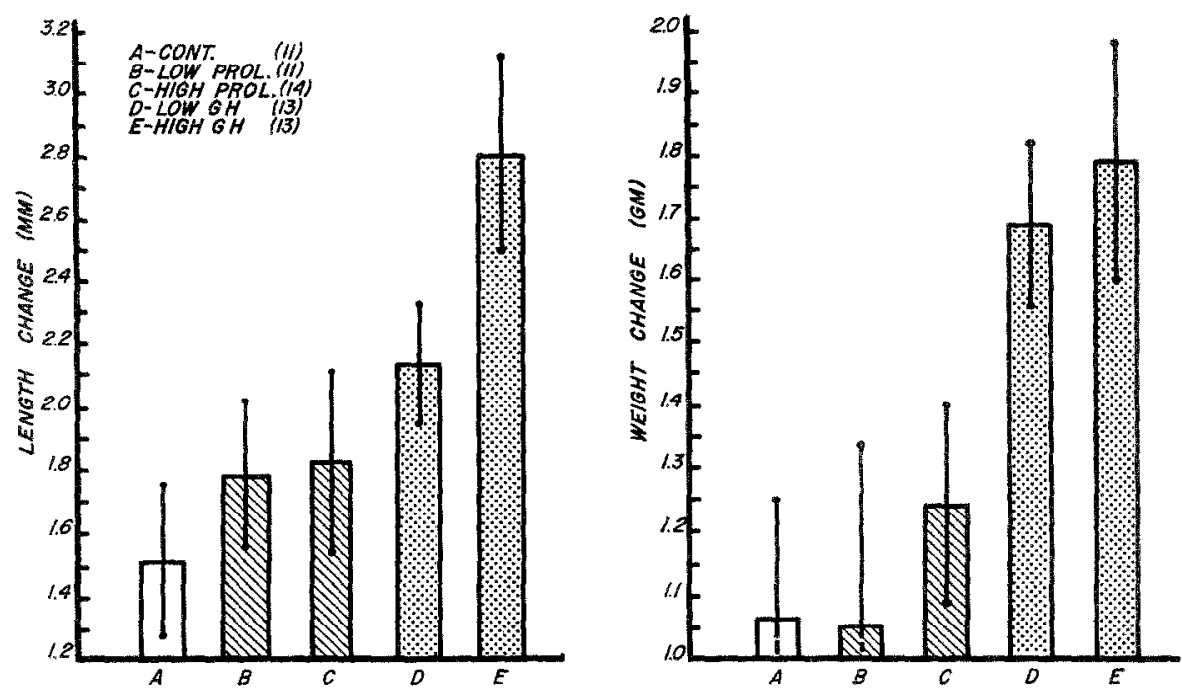

FIG. 3. Total mean length and weight changes \pm standard errors of postmetamorphic R. pipiens treated for 2 months with saline, prolactin, and GH. Group A, 2 months of saline treatment; Group B, $5 \mu \mathrm{g} / \mathrm{day}$ prolactin for 1 month, $10 \mu \mathrm{g} /$ day prolactin a second month; Group C, $25 \mu \mathrm{g} /$ day prolactin 1 month, 50 $\mu \mathrm{g} /$ day prolactin a second month; Group D, $5 \mu \mathrm{g} /$ day GH 1 month, $10 \mu \mathrm{g} /$ day GH a second month; Group $\mathrm{E}, 25 \mu \mathrm{g} /$ day GH 1 month, $50 \mu \mathrm{g} /$ day $\mathrm{GH}$ a second month.

or weight in any dose used, during any interval of this experiment.

\section{DISCUSSION}

The suppression of growth in frogs by hypophysectomy was not unexpected, although it had not been previously reported. This result demonstrates that the pituitary gland plays a role in the regulation of growth in frogs, as in other vertebrates. Although it might seem reasonable to infer from this experiment that the frog pituitary produces a growth-specific hormone, as in higher groups of vertebrates, the data do not of themselves warrant this conclusion, in view of the many other consequences of hypophysectomy which might secondarily depress growth.

As was mentioned at the beginning of this paper, and in the preceding paper (Brown and Frye, 1969), prolactin has proved to be the most effective growthpromoting hormone so far tested in tadpoles. Consequently, the finding that only GH was effective in stimulating growth in frogs, whereas prolactin had no effect, was somewhat surprising. These results suggest that, if the pituitary of frogs produces a specific hormone necessary for normal growth, it may resemble mammalian GH more than it does mammalian prolactin.

The inversion in relative sensitivity to prolactin and $\mathrm{GH}$ between tadpole and frog stages of growth is particularly intriguing: and suggests that the hormonal mechanisms of growth regulation are different in these two stages of the life cycle. Tadpoles are in the order of $25-50$ times more sensitive to prolactin than to GH (Brown and Frye, 1969) and there is room for doubt that GH-specific growth responses have been producen. Frogs, on the other hand, respond to as little as $10 \mu g /$ day of $\mathrm{GH}$, but gave no growth response to up to $50 \mu \mathrm{g} /$ day of prolactin. This difference must reflect a basic differ. ence in the hormone-response mechanism of the target tissues, and could be due to either of two possibilities: (1) the same tissues are responding to prolactin and $\mathrm{GH}$, but change their relative selsitivities to the two hormones at metamorphosis, or (2) different tissues or cell populations respond to the two hormones, and there is a change in the proportions or quantities of specifically GH- and prolactin-sensitive target tissues during metamorphosis. 
This interpretation of the hormonal regulation of growth in frogs would be greatly strengthened by information on the levels of assayable growth factors in the frog pituitary, and particularly on their activity compared with mammalian GH and prolactin. Information as to whether there is a transition in the nature of or proportions of native growth factors, corresponding to the observed transition in sensitivity to exogenous prolactin and $\mathrm{GH}$ would be especially valuable to our understanding of the nature of growth regulation in amphibians. Bioassays of adult anurans have demonstrated the presence of both prolactin-like (Foglia, 1940; Chadwick 1966a, 1966b; Nicoll and Bern, 1965; Nicoll, Bern, and Brown, 1966) and GHlike (Solomon and Greep, 1959) activities. Muller et al. (1967) have found GHreleasing activity in the hypothalamus of Rana pipiens. However, assays of tadpole pituitary extracts have not been made, and thus the relative amounts of these two kinds of activity in tadpoles and frogs are not known. Cytological data on the presence and proportions of prolactin- and $\mathrm{GH}$-secreting cell types in the pituitaries of tadpoles and frogs would be relevant to this problem. Unfortunately, although acidophils, identified with the secretion of prolactin and GH in mammals, have been described in both the frog (Ortman, 1961; Kerr, 1965) and the tadpole (Etkin and Ortman, 1960), not enough experimental work has been done in amphibians to allow correlation of cells of specific staining characteristics with specific hormones.

\section{ACKNOWLEDGMENTS}

The authors thank the Endocrinology Study Section of the National Institutes of Health for supplying the prolactin and growth hormone used in this investigation. Thanks are due also to Dr. G. W. Nace and Dr. Christina Richards for their help in supplying frogs and live food.

\section{REFERENCES}

Bern, H. A., Nicoli, C. S., and Strohman, R. C. (1967). Prolactin and tadpole growth. Proc. Soc. Exptl. Biol, Med. 126, 518-520.

Berman, R. H., Bern, H. A., Nrcold, C. S., and
Strohman, R. C. (1964). Growth promoting effects of mammalian prolactin and growth hormone in tadpoles of Rana catesbeiana. J. Exptl. Zool. 156, 353-360.

Brown, P. S., AND FkYE, B. F. (1969). Fffects of prolactin and growth hormone on growth and metamorphosis of tadpoles of the frog, Rana pipiens. Gen. Comp. Endocrinol. 13, 126-138.

Chabwick, A. (1966a). Prolactin-like activity in the pituitary gland of the frog. J. Endocrinol. $34,247-255$.

ChaDwrok, A. (1966b). Prolactin-like aetivity in the pituitary gland of fishes and amphibians. J. Endocrinol. 35, 75-81.

Epple, A., Jørgensen, C. B., ANd Rosenkilde, P. (1966). Effect of hypophysectomy on blood sugar, fat, glycogen and pancreatic islets in starving toads (Bufo bufo L.). Gen. Comp. Endocrinol. 7, 197-202.

EtKin, W., and GoNa, A. G. (1967). Antagonism between prolactin and and thyroid hormone in amphibian development. J. Exptl. Zool. 165, 249-258.

Etkin, W., and Ortman, R. (1960). Cellular differentiation in relation to growth-promoting activity of pituitary grafts in tadpoles. Anat. Record 137, 353.

Foglia, V. G. (1940). Acción de la hypófisis del sapo Bufo arenarum Hensel sobre el buche de Ia paloma. Rev. Soc. Arg. Biol. 16, 559-562.

FrYe, B. E. (1969). Hormonal control of lightdark adaptation in frog skin. In "An Introduction to Experimental Biology," (D. G. Shapirio, P. M. Ray, and B. E. Frye, eds.) Worth, New York.

HaLL, A. B., and SogorTtí, O. E. (195̃1). Effects of hypophysectomies upon the initiation of regenerative processes in the limb of Triturus viridescens. J. Exptl. Zool. 118, 363-388.

KerR, T. (1965). Histology of the distal lobe of the pituitary of Xenopus laevis. Gen. Comp. Endocrinol. 5, 232-240.

LICHT, P. (1967). Interaction of prolactin and gonadotropins on appetite, growth and tail regeneration in the lizard, Anolis curolinensis. Gen. Comp. Endocrinol. 9, 49-63.

LICHT, P., AND JoNES, R. E. (1967). Effects of exogeneous prolactin on reproduction and growth in adult males of the lizard Anolis carolinensis. Gen. Comp. Endocrinol. 8, 228211.

Meites, J., ANd Nicoll, C. S. (1966). Adenohypophysis: prolactin. Ann. Rev. Physiol. 28, 5788.

Muller, E. E., Sawano, S., and Schally, A. V. (1967). Growth hormone-releasing aetivity in 
the hypothalamus of animals of different species. Gen. Comp. Endocrinol. 9, 349-352.

Stcolt, C. S., ANo Bern, H. A. (1965). Pigeon crop-stimulating activity (prolactin) in the adenohypophysis of lungfish and tetrapods. Endocrinology 76, 156-160.

Nicoll, C. S., Bern, H. A., ANd Brown, D. (1966). Occurrence of mammotrophic activity (prolactin) in the vertebrate adenohypophysis. J. Endocrinol. 34, 343-354.

Niwelinski, J. (1958). The effect of prolactin and somatotrophin on the regeneration of the forelimb in the newt Triturus alpestris. Folia Biologica Warsaw 6, 9-36.

Orrmax, R. (1961). Anterior lobe of the pituitary of Rana pipiens 1. A cytological and cytochemical study. Gen. Comp. Endocrinol 1, 306-316.

Rémy, C., and Bounhol, J. J. (1965). Croissance exagérée des têtards de Crapaud acconcheur entiers ou privés de leur hypophyse, et subissant un traitment par la prolactine. Compt. Rend. Soc. Biol. 159, 1532-1535.

RÉMY, C., AND BOUNHIOL, J. J. (1966). Gigantism expérimental obtenu par intervention chirurgicale et traitements hormonaux chez le têtard du crapaud accoucheur. Ann. Endocrinol Paris Suppl. 27, 377-382.

Rindie, O. (1963). Prolactin in vertebrate function and organization. J. Natl. Cancer Inst. 31, 1939-1110.

Solomon, J., and Greep, R. O. (1959). The growth content of several vertebrate pituitaries. Findocrinolngy 65, 334-336.

WrLzERson, J. R. (1963). The role of growth hormone in regeneration of the forelimb in the hypophyscetomized newt. J. Exptl. Zool. 154, 223-230. 